\title{
Marktonderzoek verkoopt goed!
}

\author{
Fred Wester
}

Ruyter, Ko de \& Norbert Scholl Qualitative Market Research, Theory and Practice. Utrecht Lemma, 2003. I7Ip. ISBN 90593I2023. € 20,50.

Ereaut, Gill, Mike Imms \& Martin Callingham (eds.) Qualitative Market research: Principle and Practice London: Sage, 2002, III2 pp, ISBN 0761972722, € 250,-

\section{De Ruyter en Scholl}

Het boek van Ko de Ruyter en Norbert Scholl is een vertaling van een publicatie onder de Nederlandse titel Kwalitatief Markt Onderzoek, ook uitgegeven bij Lemma. Waarschijnlijk omdat de eerste druk van de Nederlandse versie uit I995 stamt, zijn er maar weinig verwijzingen naar de recente internationale literatuur zoals Qualitative Market Research: a comprehensive guide van Mariampolski (200I) of de zevendelige serie Qualitative market research: principle and practice van Eraut, Imms \& Callingham (2002). Bovendien is er nog een internationaal tijdschrift onder dezelfde titel: Qualitative Market Research, dat sinds I998 verschijnt. Hoewel er dus onderhand al heel wat verschenen is, hebben De Ruyter \& Scholl deze Engelse vertaling gebaseerd op de situatie dat er nog weinig bekend was over de grote mogelijkheden van kwalitatieve vormen van marktonderzoek.

Deels gericht op studenten in de beroepsopleiding, maar ook deels gericht op de praktijk van de marketeers levert dit boek een simpele kennismaking met een aantal van wat in de inleiding genoemd wordt latest techniques.

In de inleiding (hoofdstuk I, I2 pagina's) wordt een globale omschrijving gegeven van kwalitatief onderzoek en wordt voornamelijk ingegaan op de onderwerpen en soorten onderzoeksvragen die door marktonderzoekers via kwalitatief onderzoek kunnen worden aangepakt. Dan volgen twee hoofdstukken over respectievelijk individuele interviews (hoofdstuk 2), en groepsdiscussies (hoofdstuk 3), waarbij aandacht wordt geschonken aan de vormen, de opzet, de uitvoering en de analyse en verslaggeving van het materiaal. Deze drie hoofdstukken tezamen geven daarmee een soort simpele algemene inleiding in het kwalitatief onderzoek door middel van interviews.

De kern van het boek (hoofdstuk 4 tot en met 9) bestaat uit de presentatie van een aantal technieken die kunnen worden gebruikt: nominal grouping, concept factory, critical incident technique, cognitive response analysis, laddering, the Zaltman metaphor elicitation technique. Elk van deze technieken wordt in ongeveer tien bladzijden geïntroduceerd aan de hand van een korte beschrijving van een onderzoeksvoorbeeld waarin de betreffende techniek is gebruikt. Zo wordt cognitive response analysis toegelicht aan de hand van interviews die zijn gehouden bij het pre-testen van conceptadvertenties van een reisbureau. Bij elke techniek komen doel, onderzoeksopzet, interviewvragen, analysevorm en uitkomsten aan de orde. In hoofdstuk Io ('Research using case studies') wordt een voorbeeld besproken van een case study in de transportsector. In hoofdstuk II ('Online qualitative research') wordt het materi- 
aal van online discussies vergeleken met materiaal van groepsinterviews, waardoor suggesties kunnen worden gegeven over het gebruik van dit soort materiaal voor onderzoek. In het afsluitende hoofdstuk 12 worden enkele opmerkingen gemaakt over de waarde van kwalitatief onderzoek.

Dit boek is vooral interessant voor mensen die snel iets willen weten over een marktonderzoek techniek. De betreffende technieken worden op het niveau van een encyclopedie toegelicht.

\section{De reeks van Ereaut, Imms en Callingham}

Het boek van de Ruyter en Scholl lijkt op een pocketuitgave van de zevendelige Sage cassette Qualitative Market research: Principle and Practice onder redactie van Ereaut, Imms en Callingham. Deze serie bestaat uit een algemene introductie (I: An Introduction to Qualitative Market Research), waarin achtergronden en karakter van het marktonderzoek worden behandeld; een deel over interviewen (2: Interviewing Groups and Individuals in Qualitative Market Research), waarin de plaats van interviewprocedures in het marktonderzoek wordt besproken; een deel over andere methoden (3: Methods Beyond Interviewing in Market Research) met aandacht voor observatie, creativiteit, culturele analyse en internet; een deel over analyse (4: Analysis and Interpretation in Qualitative Market Research) waarin aandacht voor perspectieven, de aard van analyse, micro- en macrolevel interpretatie, computergebruik en kwaliteit; twee toepassingsdelen; (5: Developing Brands with Qualitative Market Research en 6: Developing Advertising with Qualitative Market Research) waarin de achtergronden, structuur en inhoud van het onderzoek op deze gebieden worden besproken; en een deel waarin ingegaan wordt op de overdracht van de resultaten (7: Delivering Results in Qualitative Market Research), waarin duidelijk wordt dat een onderzoeksrapport niet altijd nodig is.

Bij elkaar is de cassette een heel handboek, maar wel met flink wat overlap. Zo kan men in elk deeltje wel een onderdeel vinden over het waarom van deze methode voor het marktonderzoek en dat levert dus heel wat verschillende 'waaroms' op, die ook in een ander deeltje relevant zouden kunnen zijn.

\section{Vergelijking}

Hierboven stelde ik dat het boek van De Ruyter en Scholl het pocketformaat van de cassette lijkt te zijn, maar dat is alleen maar zo vanwege de titel. In feite gaat het hier om een variant op het deeltje over interviewen. Het voordeel van het boek van De Ruyter en Scholl ten opzichte van dat deeltje is dat zij zoveel concrete technieken en de achtergronden daarvan aan de orde stellen. Het nadeel daarvan is misschien dat het een wat toevallige keuze lijkt uit een groot aantal gangbare technieken uit de praktijk. Maar de aard van die praktijk wordt daardoor wel duidelijk: het gaat om tamelijk gestructureerde vormen van kwalitatief onderzoek, die uitgaan van vooraf gegeven invalshoeken. Daarbij laten De Ruyter en Scholl een beetje in hun keuken kijken, iets wat uit concurrentieoverwegingen bij het marktonderzoek niet altijd wordt gedaan. 
De cassettebundel over kwalitatief marktonderzoek gaat op twee praktische thema's in: ontwikkeling, door middel van kwalitatief onderzoek, van advertentiecampagnes en van campagnes voor het onderhoud van of de bekendheid van het merk. Advertentiecampagnes zijn bedoeld om tot kopen aan te zetten of om een attitude- of gedragsverandering te bewerkstelligen. Nou lukt het aanzetten tot kopen of tot gedragsverandering (bij opvattingen en verkiezingen) niet zomaar, dus veel campagnes worden al als geslaagd beschouwd als de doelgroep de advertentie heeft opgemerkt of zich het merk weet te herinneren. De achterliggende invalshoeken met betrekking tot advertenties en merken en hun werking en de opzet van campagnes, nemen het grootste deel van beide boekjes in beslag. Het zijn journalistieke beschrijvingen over wat er zoal in deze onderzoeksvelden speelt. De centrale boodschap is: betekenissen spelen een grote rol en 'dus' is kwalitatief onderzoek van belang.

\section{Conclusie}

Het zijn leuke boekjes om iets van dit soort onderzoek te weten te komen, maar het kwalitatief onderzoek komt bijna niet aan de orde. Het blijft beperkt tot een hoofdstukje met reeksen mogelijke, vaak projectieve, technieken. Kwalitatief onderzoek heeft vooral een rol in de ontwikkelingsfase van de campagne: voor het uitwerken van de strategische uitgangspunten van de campagne en bij het creëren van het campagnemateriaal (bijvoorbeeld de advertentie). Ook ter voorbereiding van de evaluatie van de campagne (bijvoorbeeld via survey onderzoek) kan kwalitatief onderzoek worden gebruikt om bijvoorbeeld relevante categorieën voor de vragenlijst op te sporen. Nou ja en zo gaat dat nog II6 bladzijden door en dat zo'n keer of zeven. Best leuk om zoiets te lezen als je er weinig van af weet.

Over kwalitatief onderzoek leer je uit deze boeken niet veel bij, maar je kunt wel snel opzoeken hoe het zit met een specifieke interviewtechniek. En als je geïnteresseerd bent in marktonderzoek, dan kom je ook nog heel wat vraagstellingen en invalshoeken tegen. Meer iets voor de bibliotheek dan voor thuis! 